\title{
From Citizen to Cytizen. How to Escape from Cyberstates?
}

\author{
Guido JM Verstraeten ${ }^{1,2}$, Willem W Verstraeten ${ }^{3}$ \\ ${ }^{1}$ Satakunta University of Applied Sciences, Tiedepuisto 3, FI 28000 Pori, Finland \\ ${ }^{2}$ Karel de Grote Hogeschool, Nationalestraat 5, B-2000 Antwerp, Flanders, Belgium \\ ${ }^{3}$ Royal Meteorological Institute, Belgium \\ Correspondence: Willem W Verstraeten, Royal Meteorological Institute, Belgium.
}

Received: October 13, 2017

doi:10.11114/ijsss.v6i1.2695
Accepted: November 6, $2017 \quad$ Available online: November 23, 2017

URL: https://doi.org/10.11114/ijsss.v6i1.2695

\begin{abstract}
The Modern Western state is characterized by unmediated individual access to wellness, health, safety and liberal human rights. The Newtonian conception of space and time makes formal room for a discursive public area with the citizen and the public institutes in the margin, while participation and ethical responsibility is a prejudice of good citizenship. It is a necessary condition of consistency and coherence of the nation. To date, global migration and multiculturalism threaten those necessary basic conditions of Western states' political equilibrium. To challenge the actual global phenomena national states transform into virtual places of fear dominated by cybernetics, digital bureaucracy while citizen's identity is mirrored by the efficiency and unisexual beauty ideal of cyborgs. The substantive conception of technology is government's tool box to realize the cyberstate while citizen reduce to "cytizen".

In order to escape from this global grey, we propose a different conception of space and time namely the Leibnizian conception of pluralistic independent participating worlds. Moreover, we modify Leopold's Land-Ethics by introducing the transpersonal identification claim of Warwick Fox inside the common Land so-called eco-homeland while the care for the foreigner serves as paradigmatic core attitude to all participants of the eco-homeland. So we constitute a common eco-refuge, similar to the ideas of Bookchin's eco- anarchistic ideas but avoiding his dialectic ideal conception of the Land and its participants.
\end{abstract}

Keywords: modern nation, oikophobia, cytizen, cyberstate, Homeland-Anarchism

\section{Modern Management of Public Space in Western Communities}

The Newtonian space-time concept starts from an absolute point zero of space and time while space-time is a homogeneous, continuous and empty vacuum. The absolute spatial and temporal point zero is the creation of here and now instead of nowhere and never (Rijnvos, 1996). Though Newton's formal foundation of classical mechanics is straightforward, his legacy for Modern Western rational way of thinking is underestimated. Thee Newtonian conceptions are the prime condition for the rational metaphysics of DesCartes and the criticism of Kant, while both philosophers influenced deeply the intellectual life of the Enlightenment Era. Particularly Newton's conception of space and time influenced Kant's spatial and temporal conception as transcendental propensities of human mind deeply. Time and space do not have any reality, but order objects simultaneously respectively diachronically, while the observing and deliberating moral subject stands outside the unique homogeneous four-dimensional Newtonian space-time. Furthermore, modern public area is formalized according to Newtonian mathematical representations of space and time. So Taylor (2004) claimed the extraterritoriality of any subject's needs and interests and the immediate access of all subjects to the national public area. Any human action is rooted in his own indi viduality and not derived from one or the other transcendence or tradition, nor does the homeland. Human action is governed by universal duties and rights and are embedded in progress of welfare and wellness, so called 'common good', without any restriction but ratio. The core business of common good means safety, healthiness and wellness. That is why the public area makes room for justice, good education, infrastructure for public health and mobility. Moreover, any citizen is supposed to participate to the public area according to citizens responsibility (Waldron, 2000).

We put forward three critical remarks on the above Enlightenment blue print of Modern public area. Firstly (i), a paradox appears between the real deliberating individual moral subjects who aspire universal rights and common good and the vague ontological and moral status of any community within the public area. Indeed, representatives of 
Anglo-Saxon political philosophy as well as Continental thinkers put forward the Enlightenment conception of public area as public scene of individual interests. Moreover, the public area is even not a particular physical space but an ideal discursive space based on fundamental human rights such as equality, freedom, and brotherhood. Each citizen is supposed to share active citizenship based on these three theoretical ideas of the Enlightenment while public space reduces to a formal toolbox of political devices making room for citizen individual emancipation. For instance, Locke started his ideas about the community and citizenship essentially from universal and unchangeable human needs far from any tradition and particular history within a timeless public space wherein people realized their life's for ages. Voltaire claimed Enlightenment citizen emancipation, provided it starts from individuals capacity to discern moral worth and moral priority within public space (Voltaire, 1928). Enlightenment concept of community is nothing more than a conglomerate of similar interests.

Secondly (ii), to civic responsibility, Neumann (1992) added active citizenship and ethical dimension. The latter is not based on pure rational grounds but is considered as a necessary condition to belong to the society. In addition, MacIntyre (1981) claims a common ethical horizon to avoid a complete deny of common moral project. Moreover, according to Charles Taylor a public life without moral horizon implies pure nihilism:

... If we do not, then the quest for self-determination leads to Nietzschean nihilism, the rejection of all communal of life, Christian and humanist, are cast off as shackles on the will. Only the will to power remains ... (1979, p. 159).

In addition, Sandel (1982, p. 183) concludes that the common moral horizon precedes the moral self-determination:

... A politics of the common good, by expressing these shared constitutive ends, enables us to know a good in common that we cannot know alone...

However, with Kymlicka (2002) we put doubts about citizen's capacity of ethical sensibility for responsibility deprived from his bag pack of social and historical feedback. How can the self-determining and moral sensibility proceed the community when active citizenship build up according to an ethical standard imposed by the community? Indeed, we share Kymlicka's claim (2002) that any public place of any Western community is not a neutral moral space but precedes any individual moral project. Moreover, the Western public community is almost politically instituted by states and nations. Citizen's identity roots in the public tradition of their respective state or nation. Obviously, identity does not reduce to a monolithic connotation because any nation nourishes its own tradition. The role of tradition and the way how to deal with the past is straightforward for actual and future individual identity as well as for the mutual responsibility within the public space.

Thirdly (iii), what does individual identity mean? Does it influence the individual self-determination of the citizen within the Modern public space? According to Charles Taylor (1992), identity is connected to the notion of authenticity, the claim of recognition, the feeling of difference and the principle of adjusted equality. Authenticity implies that any individual citizen can handle and behave without any unnatural adaptation in order to be accepted as member of the community. Recognition means that the community makes room for any member according to his deep existence without any conditions. Moreover, recognition makes room for dialogue with any moral subject. The acceptation of difference is a necessary condition for authenticity of any member so that no member is reduced to the principle of what's sauce for the goose is sauce for the gander. However, identity is not synonymous of indi viduality because any national belongs to a social network that forms precisely the guaranty of his identity. In consequence, the way to get his own identity is to embrace the nation as the place of self-understanding. It is the place where you feel save, the place of ethical consideration. Individual citizen and the community constitute one organic body. At first glance this place cannot be identified with the formal Newtonian inspired public space of individual interests.

Accordingly to Sandel (1984), the intentional ethical horizon constitutes the self of any individual and it implies individual autonomy, tolerance and diversity and freedom of consciousness. Furthermore, the ethical community precedes the moral individuality and that individual self-determination is not based on the moral preferences of the citizen but on the basic moral standards represented by the common horizon or the realization of the common goods. Besides human rights, the community has a double task. On the one hand, it has to make room for social, economic, psychological and philosophical wellness of any individual citizen. While on the other hand, community's aim is to encourage any citizen to make part of the community by creating a widely accepted public life, often far from anybody's individual needs and wishes. But how can these claims be commanded within a Newtonian formal scope of public space and time unless we attribute ontological status and moral subjectivity to communities? Berlin expressed it in the following quote:

... these rules or doctrines or principles should be followed not because they lead to virtue or happiness or justice or liberty... or are good and right in themselves... rather they are to be followed because these values are those of my group-for nationalist, of my nation ... (1981, p. 342-3) 
Bearing the three above mentioned critical remarks we shall demonstrate the deficiency of the Enlightenment public space faced with new challenges of a globalized political, social and economic space, global migration and the multicultural society and eventually the ubiquitous power of technocracy. Eventually, there is need for a new basic conception of public space and time to safe one of the forgotten consequences of the Enlightenment legacy, namely, political and cultural diversity in ecological equilibrium with the environment.

\section{Challenge of Globalization and Mul ticulturalism}

To date, we are faced with the greatest challenge since Modern Times. Indeed, economic globalization is accompanied by equalizing social classes, races, gender and people, but also with worldwide mobility, legal and illegal migration and last but not least environmental problems. Obviously, Earth is extremely stressed by our human activity. Since 1972 we consume more per annum than the Planet can afford. Lack of ecological sustainability, however, cannot explain exhaustively the actual super floods of migrating people. The core explanation for this recently increasing legal and illegal migration is not uni vocal but rather are an interwoven concatenation of ecological, demographic, social, political and economic reasons. That Canada, the US, Australia and the EU are so attractive destinations for immigrants is due to their high standard of life, the political stability and the complete absence of any risk for war or civil troubles. At face value war, political instability accompanied with violence, poverty, ecological catastrophes involve huge numbers of refugees, but furthermore the tremendous inequality of world's wealth, encourage people of any walk to look for better conditions of life in countries with high standard of life and with a good network of social support.

The global migration throughout the Planet hearths nation's coherence. In addition, lack of common tradition involves breakdown of national convergence while ethical care for public space of modern states and nations is no longer univocal. Particularly, the achievements of the Enlightenment emphasized the idea of individual emancipation and makes room for a one-dimensional concept of self-emancipation including individual progress. Any private is situated in a cosmo-political concept of the Planet that ends finally in a deep feeling of oikophobia of any national subject. The actual coherence of the globalized communities is contestable and the ethical conception of wellness, goodness and welfare are not necessarily converging.

But, can the Western civilization and its institutes resist to this huge external demographic stress without collapsing or is there a need for a complete different institutional organization of our planet in order to avoid a more fundamental catastrophe, namely the complete ecological, cultural and political collapse of Earth? Moreover, the modern state is faced with other external stress because the global open world is not enough. There exists an additional virtual world wide web with virtual social media, virtual contacts and virtual money. Finally, what happens when the national public area collapses? How to actualize a mosaic of traditions on a common public space when time is no longer the diachronic series of events and space is no longer a place to live? What about Benjamin Barber (1996) claim that a return to tradition and national borders, instead of complete globalization of human society would end into a chaotic breakdown of the public space in all its human and ecological aspects? Are we indeed reaching the great desert of Lyotard's postmodernism (1983) wherein everybody cries but nobody responds?

\section{Strategic Political Answer to a Multicultural Global Public Area}

The Enlightenment political rationale does not make room for a clear ontological status of community, neither for a real spatial and temporal public space, nor for an intentional ethical horizon as anchorage place for self-determination of the individual citizen. Nevertheless, Western countries try to manage the new challenge by four political strategies based on the core principles of Western civilization. Therefore governments create oikophobia rooted in the already above mentioned conception of space. Supranational institutions reduce cultural and political traditions - particularly the role of mother tongue in education and general political debate - to subject of entertainment and folklore. Within these artificial political places of fear and self-alienation ethical care for all participants of the public space is no longer a honest path to realize justice but a formal procedure to reach pragmatic fairness. Moreover, timeless virtual constructions dominated by technocrats govern the public area. Finally, this new timocracy makes room for a rather substantive vision of technology while in fact social constructivist technological strategy is tacitly imposed on the respective multicultural population of the Western countries'subjects.

\subsection{Oikophobia and Procedural Ethics}

Recently, the Enlightenment political space based on Kant's transcendental conception of space and time is claimed again by Allinson (2002, p.42). Continental philosophers as Bergson (1970) and Poincaré (1913) claimed vague and continuous space and time that can be completely constructed by the thinking subject. Within this continuous reality the external ultimate order is imposed top-down as Newton imposed the absolute beginning of time and space (Rijnvos, 1996). The modern world is like the monotonous world of Swift's Gulliver Travels, wherein all is correctly organized, all looks the same at any place and at any time but it is a boring world of sad men. While Swift wrote a sketch of the coming modern world, Piranesi performed the modern world by his famous painting called Carceri, jail, prison. Within 
Piranesi's modern world all rooms are similar and painted in the same grey colors. It is impossible to find your way and some parts are just like the imaginary castle and houses you can find in computer games. This $18^{\text {th }}$ century art predicted the architecture and organization of our post-modern world. More recently, the idea of alienated and disoriented subjects is also mentioned by Bachelard (1969) and Yi-Fu- Tuan (1974), in a complete different context of causing fear space. Moreover, within this multicultural public area of fear and alienation any citizen of any liberal state is supposed to transcend one's ethnical, religious and other particularities by thinking and acting as member of his political community (Parekh, 2006, p.181). However, the modern state is not a culturally neutral instrument of order and stability, it is embedded in a particular pragmatic vision of order and stability. Furthermore, according to Parekh (2006, p.184), the citizen is subjected to the authority of the formal law only. The state requires from all its citizens the subscription of defining themselves in relation to each other and the state according to an identical procedural way. This political pragmatic and formal self-understanding is the constitutive principle and necessary preposition of any multicultural state.

To establish this juridical pragmatic public space public institutes claim also a extern virtual position of space and time, by idealizing the irreversible order of facts and transforming it to a phenomena of eternal return of the global progress (Roshwald, 2006). In order to enforce its meta-temporal position, the public institutes behave as meta-religious institutes (Smith, 2003) and organize pseudo-religious memorials. Vick (2002) and Zerubavel (2003) consider this extern position as a strategy to present the government as the universal and unique common good so that the insignificance of the citizen becomes straightforward. (see Caluwe \& Verstraeten, 2014).

\subsection{The Global Virtual Public Area of Supra-national Governments}

Government's position is very similar to the absolute status of the Aristotle's Prime Mover with respect to the whole continuous space and time top-down filled with naked events. Education, work, body's integrity, life, autonomy of any walk, culture and creativity are governed by top-down authority, which legality is based on rational arguments of the Enlightenment. Law and moral life is submitted to the Universal Declaration of Human Rights which are supposed to be timeless without any connection with the local do's and don'ts.

In consequence of the Enlightened ratio, formal procedures reduce the human subject to procedures represented by ID-Cards, civic service-numbers and bonus cards representing subject's consumption pattern. Moreover, the own identity built up by mother tongue, culture, religion and the homeland are banned to the private because these aspects of life are particular and difficulty manageable according to some procedure. Any subject does not become citizen of a village, town or homeland, but an anonymous momentum in a concatenation of administrative procedures. The living space is codified according to quantifiable parameters measuring wellness, welfare, education level of subjects. No trace of tradition of homeland can be recognized within the management of the modern super state.

Subjects get a life codified by Brussels, Beijing, Washington or Moscow. Objects of any walk lose their space-like and time-like connotation and so does any subject. The latter policy provokes social and cultural alienation and enforces the above mentioned oikophobia (Caluwe \& Verstraeten, 2015).

Human beings, however, are cultural creatures. Culture embodies common structure and gives sense of identity to its members. Actually, culture is apparently reduced to an instrumental role of autonomy-building and creation of stability of the globalized world, though in a narrow liberal sense. The supranational policy denies traditions of local cultures, local institutes and even instruments of coherence. Eventually a reasonable global justice destroys any national historical coherence and in consequence member's perceptual and moral world, member's sense of rootedness and their focus of identification.

Globalization as Enlightenment fulfilment finds its end in global communication by the world wide web. Social media give the impression that people have contacts all over the world, but instead of contact with human beings as real friends, just standardized profiles are met, consuming the same normalized food in a globalized but virtual world. There is no longer room for diversity, tradition, mother tongue and proper social and economic action because being time-like and space-like sounds contradictory to universality of the human rights declaration and in consequence human beings connected to their land and tradition are a source of fear. For all of us there remains just one global similar identity of consuming the same products with a formal homogeneous cosmopolitan citizenship without cultural and traditional background and that all because of fear for being from a particular place and in a particular time (see also Evanoff, 2010, Chapter 1).

\subsection{Technology as Ultimate Global Pseudo-Neutral Strategy}

Since Modern Times humanity considered scientific and technological evolution as an autonomous process, out of any dogma and nobody would deny the fruitful spin-off of all technical devices. Moreover, technology dominates as transcendental rationale our daily life just as natural laws are governing the Newtonian laws of mechanics. 
This era reveals the hidden secret of technology, namely rationality, the drive for efficiency, the increasing control and the calculability. Max Weber (1994) called this world the iron cage of rationality that enters into social and psychological life, excluding all feelings and sentiments that cannot be expressed in numbers and statistics. According to this so called substantivist conception of technology the world is one web of which we make part of it. The web is revealed and ordered according to definite rational manner. Technology is one mode of revealing. It forms a culture of general control. Everything, even humans are reduced to raw materials, everything loses its integrity as part of the coherent world and is levelled down to an object of pure will (Heidegger, 1977).

Ellul (1964), however, claimed a political role for technology. According to this French philosopher the technical phenomenon characterizes all modern societies regardless the political ideology. Administrations impose rules on public area by what they call scientific arguments, while it is just the rhetoric that is scientific, not its practice. Though technology is political neutral, propaganda, advertising, social media invades the communicative public sphere so that top-down politics put our life world into the Era of Technocene. Obviously, background of actual power of information by world wide web makes room for governments and supranational institutes to influence the public opinion and to overrule the existing traditional familial, social and common relations. Their messages sound uni vocal: Technology is autonomous, free of our will or any human action. It is no longer the majority's vote adopting the most acceptable way of governing the public space but technological devices as the product of scientific morally neutral research.

Indeed, technology rules the right speed for take-off, the right speed for landing. Technology rules our wellness, decides if an unborn child may live or is aborted, it decides if the tumor revealed by a scan can be cured or it sends the patient to the palliative room.

\section{From Citizen of Nations to "Cytizen" of Cyberstates}

Since consistency and coherence in the social and cultural public space and tradition is lacking, substantivist and in consequence rather deterministic conceptions of technology in public space are adopted just to create this coherence and consistency in the political management of the space. Within the Enlightenment rationale they have no other choice unless governments in the spatial and temporal margin engage technological timocracy to manage the public space as container of scientific facts. Though the last 2000 years are considered as Anthropocene in the academic world, the new Era would be better determined as the Technocene. This Era of Technology is an essential consequence of the Enlightenment option for emancipated individuals living in a Newtonian world and it starts when Lyotard's postmodernism ends. Postmodernism is built around two basic concepts: the end of the Great Tales and the dead of the traditional individual human being (Lyotard, 1983). There is no overwhelming Tale such as ideology or religion that makes room for absolute truth and moral code. Without ideology there can be no nation state that claims to create the absolute good environment for citizenship. From now, nobody can impose his ideology as the unique and absolute truth. However, the Era of Technology overcomes this shortcoming consequence of the Enlightenment, at least that is what supra-national governments try to do.

It should be rather naive to think that new technology has only an instrumental meaning. Technology changes our conception of community, relations between humans and their self-created environment and even the conception of nature. Moreover, technology deals with the common life of everybody. It influences our conception of democracy, citizenship, self-identification, self-emancipation and eventually it creates a new conception of wellness and God.

Within the public area of Technocene real power is information. Technocene is a digital world. It is a scene of copies, we cannot longer make the difference between the original and the copy. The digital media are consequently changing our world. What is virtual and what is real? What news is fake and what is based on facts? The difference becomes very small, smooth and vague. Representation and simulation are mixed. Media are no longer the monopoly of the national governments while the world wide web makes room for activists of any walk, populists and terrorists to influence the public opinion and to overrule the existing social and political relations. However, it is also the public scene of promotion campaigns by the dominant political technocratic elites who govern the actual postmodern public area. As Macpherson already mentioned (Macpherson, 1977) those elites transform the political public area to an economical free market wherein human rights such as safety, health, education, entertainment, employment, social security and culture are commercialized and distributed just like any other consumption good.

The boundary conditions for such a political market is precisely the global multicultural society. Indeed, the postmodern human being is flexible, without deep hard core of tradition. His identity and individuality split into a mosaic of layers, connected to a network of social relations, real and virtual as it is the case in social media. We are no longer individuals, we are profiles within an ocean of social waves. Bauman (1991) introduced the term Liquid Identity' of the postmodern human being. The so-called unified political market makes room for freedom of man's outing. The postmodern man expresses himself as hetero or homosexual, male, female, transgender, sadomasochist or drag queen, foody, nerd, yuppie, happy single, ecologist, volunteer, feminist, all is permitted provided the new citizen accept the 
rules of the globalized elites, the so-called first world people (Evanoff, 2010). Citizen's gender identity is vague, its sexual preferences ambiguous, its behavior is rather technical. Gent's or Ladies fashion converge to cyborg's Star-Trek uniforms. The difference between high and popular culture is disappearing. Culture is rather a way of living within a specific social and political context. Culture is a cut and stick. Culture is a liquid, it has no definite form and its relations are never long living, differences between men and women are disappearing completely. Besides, the Technocratic policy is also served by the development of Artificial Intelligence and Cyborgs because there is a temporal and spatial correlation between the above described virtual postmodern public area and the cybernetic post-industrial world of computers and worldwide webs. Virtual public area involves data society, information webs and the service community. According to Clynes' conception of technology (1995) human being's life was always deeply connected to technology. Particularly new humanism will be transformed in trans-humanism that dominates the virtual cybernetic public area. All faculties of 'wetware' or the human body can be embedded into cybernetic software and hardware. Clynes and Kline (1995) introduced the term Cyborg to create humans equipped by implanted devices and technical proteases. But the actual citizen, however, is a mix of technique and organism in order to approve the potential skills of the latter. In addition we introduce the term "cytizen". The cytizen is endowed with adapted technical devices so that his memory becomes stronger, faster and more efficient with respect to human's behavior in the environment. The cytizen communicates to public and private sphere with electronic devices, he applies for official documents online, he participates to elections online, he pays it taxes online and he shares with the government his consumption pattern paid by credit cards and eventually his roundabout by his GPS. The human body is a dead body, a deficient body but it starts a new life in the skin of a cytizen. Furthermore, the dominance by web servers and providers is at face value and so is the central dominance of the supranational executives. Just like cyborgs the cytizen virtualizes the human body and human's citizenship. In addition, contradiction between the volatile and weak woman and strong and virulent man disappears in the virtual public area of cytizen. The virtual public area critics the traditional role of man and woman and it shows a world without hard working people. No social and economic justice creates equality between man and woman, nor between people from North or South, neither between white and black. It is technique that will replaces these relicts of past injustice by a unisexual world mastered by wetware organic but technically powerfully dominated cytizen. National states transform into Cyberstates. However, this virtual public area denies the complexity of social human relations, the a priori material boundary conditions of any human realization and the complex connection between body and human mental potentiality.

As Donna Haraway (1996) claimed in her essay 'The Cyborg Manifest' this cybernetic organism makes part of utopia that will be the world of a post-human identity far from the Gothic nostalgia to a world of male and female gods. The latter were just like humans but with an extreme power or special skills. They were look-alikes of gods of the Ancient Greek Time. In fact, humans were not considered as purely natural but as a cultural and technological project. Consequently, cytizens are the go-between of nature created by God and the world of technology established by human beings. Moreover, supra-national governments communicate to their subjects by means of digital canals and they offer their public services by means of reproducible Cyborgs. The latter are not only the go-between nature and citizen of a real national public space but also spaceless and timeless mediation between supra-national cyberstates and their cytizen.

\section{The End of Multicultural Diversity: Side Effect or UltimateAim of the Supra-national Cyberstate?}

Diversity of the multicultural society is expressed by differences of communication (Hall, 1990), differences in action (Klückshohn, 1962), finally by diverging cultural dimensions (Hofstede, 2001). Particularly the latter produced outstanding research about cultural diversity in the scope of renunciation of power, short or long term action, avoidance of doubt, individualism or communitarian, masculine or feminine social pattern, indulgence or restraint. Hofstede started his experimental research in 1981 in more than 80 countries. His reports are considered as standards of do's and don'ts of multinationals with plants all over the world and represent the diverging cultural dimensions especially propagated by public national state institutes, created since the Enlightenment. Strasser (1981) rooted this conception into the Enlightenment ideas about humanity adopted by the intellectual and economical upper-class of the $18^{\text {th }}$ century in Europe and America, while the popular local culture was denied and even depreciated. In most cases the upper-class spoke a different language, they had international contacts and dominated the political, social and economic space completely because popular vote did not exist. Obviously the public state institutes are shaped according to upper-class needs and conceptions about humanity imposed on the down-town people while the latter had to assimilate into these alienating bourgeois' world. Furthermore, the upper class monopolized also public communication and public education. In consequence the unique path to emancipation for lower class people consisted in adopting the cultural and social way of life of the dominating public classes. In fact Hofstede's outstanding research results represent the cultural diversity of national administrative institutes mirroring first world conception about intersubjectivity, space, tradition, time, power, fashion and nature. Moreover, Hofstede considers essential cultural diversity petrified in the same way as the public 
national institutes and their administrative institutes already mentioned by Roshwald (2006), Smith (2003), Vick (2002) and Zerubavel (2003).

To date, however, nation states make room for common economical markets that claim political status just like the European Union. Though Europe is a mosaic of cultural diversity the European nomenclatural nicely settled in a restricted area of Brussels impose global regulation in the field of trade, industrial production, energy consumption, agriculture and even education and professional training. Concerning the latter cultural and educational exchange schemes - see i.e. Erasmus and Socrates projects - are encouraged and substantially supported by the EU commissioners in order to create a new high educated EU elite. Some intellectual founding fathers of these exchange programs like professor Eco Umberto and author of the bestseller 'In The Name of the Rose' pretended that these educational exchanges would involve also private exchanges. He proposed the creation of one unique high educated European timocracy putting Europe's cultural diversity but eventually also the political national diversity in the hidden sink of petrified national relicts. Moreover, the adoption of a substantivist conception of normalized technology enforces the creation of the above mentioned technocratic timocracy communicating and managing the public space with the same technical devices.

Hence, the rather essential conception of cultural diversity disappears or becomes irrelevant in a society dominated by a substantivist conception of technology. That means that we make room for pure cultural relativism, global technological dominancy and finally the end of the multicultural diversity. The leaders of the new political space manage the public area just like a ceo of a multinational. Both are surrounded by technocrats who are just responsible for a small committee, far from the elected represents of their common subjects. The nationals of the past are transformed into profiles of a public supranational cyberspace. Diversity in the field of gender, religion, mother tongue and cultural tradition is reduced to the private because diversity of the citizen has to be transformed into the technological homogeneity of the cytizen.

Figure 1 illustrates the relationship citizen - public area in Western communities affected by globalization and multiculturalism (i) and technology (ii). The citizen evolves to the cytizen.

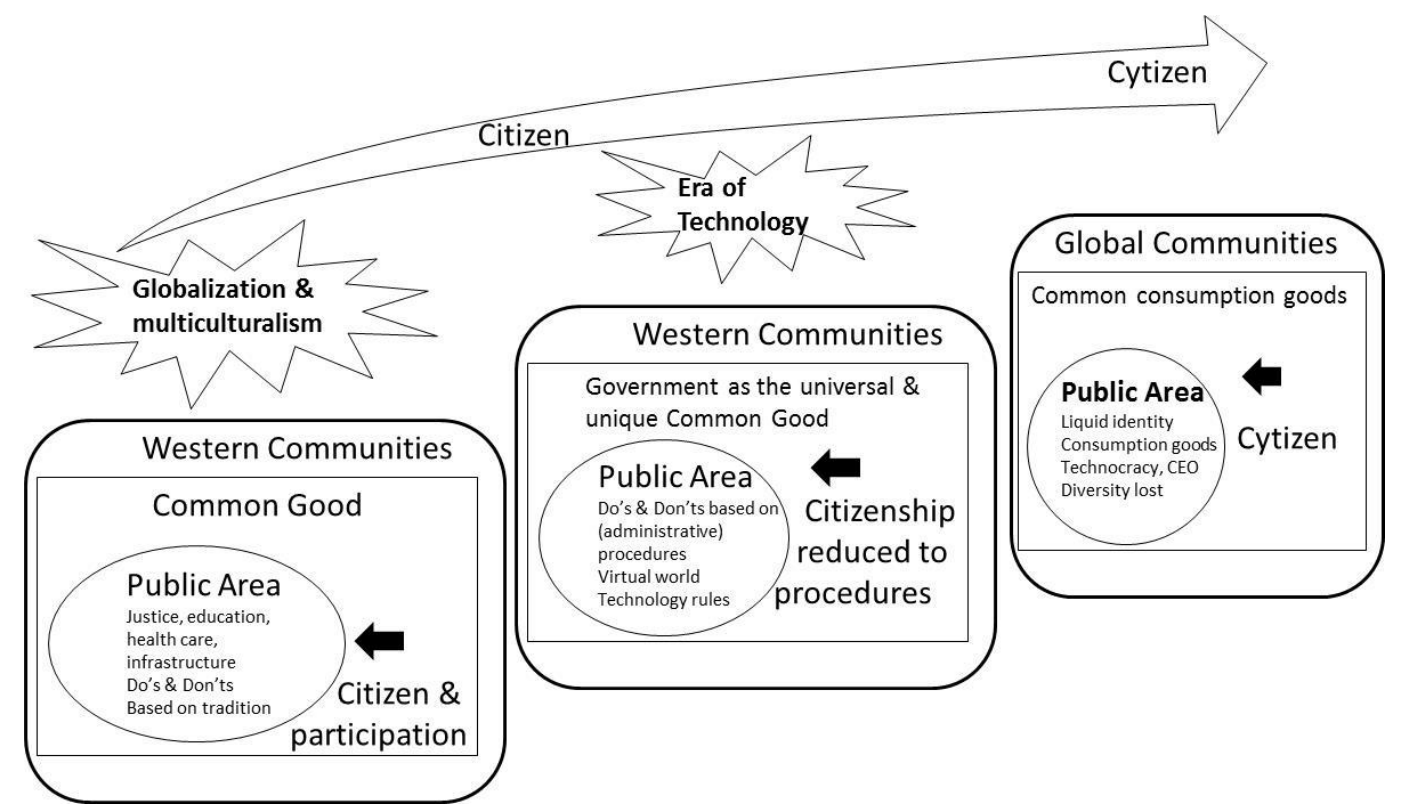

Figure 1. The evolution from citizen to cytizen. The relation with the varying meaning of public area and common goods which are rooted in Equality, Freedom and Brotherhood

\section{The Failed Escape of Green Acti vism from Cyberstates}

During the second part of the former century several outstanding philosophers formulated a quite different vision within substativism about technology and its role in the public area. Particularly, we cite Michel Foucault because his claims about the substantial power of technology imply also an attempt of escape from the cyberstates of cytizens. Michel Foucault (1976) claims that knowledge of technology and particularly of cybernetics does not intervene in terms of their universal value such as truth but under the local horizon of the social practices, artefacts and associated hierarchical relations. Since the Enlightenment the latter are deeply connected to freedom and progress but all social and political relations are realized by means of the triad 'science, technology and (private or public) capital'. Decision making does 
not have to start from the world wide globalization slogan 'think global, act local', but from the slogan 'think local, so you can manage the local effects of the dominant global cybernetic triad'. Foucault situated the resistance against hierarchy in the structure of the power-relation itself, that means that any technocracy involves its subversion. Subjugated knowledge arose in association with resistance and can produce a re-codification of the technical code. The resistant agencies are (eco)-anarchists, green activists, autonomists. According to Michel de Certeau (1980) these marginal agencies operate from the edge of the community where they can react only tactically against the strategy of the dominant technocracy. Indeed, technology and technical devices as instruments of the technocracy contains a multiplicity of codes that coexist in any society due to the indeterminism and under-determinism of any technological device. This makes room for green activism and an alternative technological code. Foucault's action in the margin is faced to an ontological problem due to hidden assumptions about the ontology of Planet's space-time. Indeed, Foucault claimed that reality cannot exist beyond text and its structure mirrors reality's structure of space-time. Moreover, Foucault emphasized that the margin determines the meaning of texts. In addition, action in the margin is a substantial element to change the whole strategic meaning of the text. That means, however, that within the margin text is just an open container of represented facts filling up the Newtonian space and time. Within the Enlightenment rationale the activists cannot give an appropriate answer to the vague ontological status of community, the absence of equilibrium between citizen's and public moral projects, eventually spacelike and timelike self-determination and virtual place and time. In consequence, activists of any walk substitute the technocratic dominance for a while to be recuperated by the first world technocratic timocracy of Cyberstates shortly afterwards.

\section{About Land-Ethics, Hermeneutics and Eco-homelands to Save Diversity}

The very reason for a substantivist and in consequence rather deterministic conception of public space, time, technology and its dominant role in political, social and economic space start from the a priori rationale of space and time. Nevertheless, the public space as part of the national territory plays a substantial instrumental role to establish stability, coherence and cultural identity: it encloses its members and gives them a distinct geographical and political identity including a collective name. Historical time flow of traditions establishes collective memory of all national subjects. According to our opinion there is only room for escape from the cyberstate if Enlightenment's heritage of rational thought and truth will be completely reversed.

Our first step to escape from the iron cage of cyberstates is to adopt the Leibnizian space and time concepts. Hence, subjects are participating to space and time instead of standing outside (i). And so do the public institutes (Verstraeten \& Verstraeten, 2005a). In consequence, Foucault's claims cannot be embedded into the scope of the Leibnizian concepts because the Leibnizian conception of space and time, however, does not imply margins.

Secondly (ii), we reject the nude Modern Times metaphysics and we make room for Gadamer's hermeneutical metaphysics $(1975,1977)$ consisting of two essential moments where tradition as first moment actualizes in the second moment of the presence (Verstraeten \& Verstraeten, 2014a).

Thirdly (iii), we rethink Leopold's conception of Land-ethics (Verstraeten \& Verstraeten, 2014a) in combination with Callicott's global metaphysics of the land $(1987,1993)$ by rethinking Fox extended eco-centric ethics and the claim for transpersonal self-identification of any eco-participant (Fox, 1986) (Caluwe \& Verstraeten, 2014). The result is a modified ethics of public space and public tradition where all participants, human and non-human and even the landscape are responsible for common space and time. Common space and tradition is transformed into the homeland wherein no subjects - the public institutes neither - can escape nor be marginalized because all participants create an eco-anarchist space and time (Verstraeten \& Verstraeten, 2014b). Particularly care for the foreigner is the basic cornerstone of the modified Land-ethics and Land-metaphysics within the eco-homeland (Verstraeten \& Verstraeten, 2016). We emphasize the substantial role of a real public space as guarantee for coherence and convergence of the eco-homelands.

Fourthly (iv), we abandon the pure liberal conception of individuality, emancipation and human rights because there is no room for an isolated single subject and we adopt a rather communitarian conception of human being, self-identification and ethical care. Indeed, globalization denies the civil society as the unavoidable key for any subject to meet the environment and to take care of it. Within the eco-homelands civil societies, however, are not only to integrate the individual in the ethical community by inter-subjective interactions as Althusius claimed (1995), but even the supra-personal inter-subjectivity as Warwick Fox suggested (1990). Therefore the institutional eco-community, the so-called homeland, had to invest in the proper immaterial and material infrastructure. Therefore the homeland needs the civil society as an informal community providing a moral infrastructure for individuals and guaranteeing of diversity and differences of all participants within the institutional public (Etzioni 1996). Moreover, Etzioni emphasizes that the nation is not the final purpose, it is no final super-society, but it is just the balance of the moral participation of citizen and moral requirements in the public space. We extend his claims to all participants of eco-homelands, humans, non-humans and the land. In addition the homeland needs 
technology as tool to realize wellness, freedom and wealth for all.

We emphasize that globalization claims the end of the boundary conditions of the Enlightenment social and political achievements. This means not only the end of the national states but also the absence of any gauging institute that balances the universal and non-temporal human rights of any private and the space-like and time-like substantial role of the civil society for which territory and tradition are indispensable.

Contrary to substantivism, we claim a social constructive role of technology in the scope of the above mentioned public space (Verstraeten \& Verstraeten 2005b). Social constructivism is a constructive action to discover scientific facts. According to Hacking's claims (1999) social constructivism queries the sphere of inevitability, which is typically the claim of positive sciences governing the substantivist approach of the politico-economical first world technocracy. It puts restrictions on the natural essence of physical processes and on the determinism of the underlying governing scientific laws (Verstraeten \& Verstraeten, 2014b). It defines tools and aims to realize in the public space.

Finally, the 'Eco-homeland' citizens belong to the civil society that stays in equilibrium with the landscape and all forms of biological life based on mutualism and Hannah Arendt's agape (2005). The land appears as an ensemble of boundary conditions according to which men and women are living together in absolute diversity and freedom of thinking, speaking and acting, called the political reality. This "Eco-homeland" or Eco-refuge guarantees freedom in diversity (Hannah Arendt 2005, p. 94) of the eco-citizen.

\section{Conclusions}

The Newtonian conception of space and time as fundament of the Enlightenment rationale prevent the ontological status of the community though the individual emancipation of any subject implies a commonwealth to implement human rights and needs. Moreover, moral projects of subjects require a common approval and in consequence an ontological status of the community. In addition, self- identification of individual is spacelike and timelike though space and time do not have ontological meaning in the Newtonian space and time. Therefore governments need political, cultural and social coherence of their individual subjects in order to realize the political Enlightenment public area. However, economic and demographic globalization within a Newtonian public space without borders create the multicultural society that treat the political coherence by lack of common culture and tradition. Governments adopt technological substantivism dominated by supranational technocratic timocracies in order to create at least a cybernetic coherence of their citizen Artificial Intelligence and Cyborgs facilitate this political process. This Era of Technocene transforms citizen into cytizen and the (supra)- national state into the cyberstate.

Leibnizian conception of space and time, however, involves a rather communitarian conception of subjectivity, spacelike and timelike - while the civil societies constitute the core communities of any nation. By modifying Leopold's Land-Ethics and Callicott's metaphysical foundation of care for the Land, we define the eco-homelands within the public area as alternative nations. Our claims of modified Land-Ethics is based on the particularity of space and time according to the above mentioned Leibnizian conceptions. Within the homeland, care for the foreigner is paradigmatic for care for all participants of the homeland, humans, non-humans and the landscape. Furthermore, within a common territory the civil societies guarantee the coherence and convergence of all eco-citizen within the public eco-homelands. The institutional public area of the eco-homelands also participate to the public area just as all members of the homeland, human, non-human and the land. Therefore eco-homelands are mirroring the eco-anarchist options of i.e. Bookchin $(1994,2004,2007)$ but avoiding the dialectical rationale of Bookchin's eco-anarchism (Verstraeten \& Verstraeten, 2014b). That is why we call our political modified Land Ethics homeland-anarchism.

\section{References}

Allinson, R. E. (2002). Space, Time and the Ethical Foundation, Harvard: Harvard University Press.

Althusius, J. (1995). Politica Methodice Digesta, 1609, ( $3^{\text {rd }}$ edition 1614). An abridged English edition of the third edition was published as The Politics of Johannes Althusius, ed. by Frederick S. Carney, London: Eyre and Spottiswoode, 1965. reprint, Politica, Indianapolis: Liberty Fund.

Arendt, H. (2005). The Promise of Politics. New York: Schocken Books.

Bachelard, G. (1969). The Poetics of Space. Boston: Beacon Press.

Baird Callicott, J. (1987). 'The Conceptual Foundations of the Land Ethics', in: Companion to a Sand County Almanac: Interpretative and Critical Essays(J.B. Callicott, ed.), Madison: University of Wisconsin Press, 186-217.

Baird Callicott, J. B. (1993). The Land Ethic Today. Topoi, 12, 41-51. https://doi.org/10.1007/BF00769815

Barber, B. (1995). Jihadvs McWorld, terrorism's Challenge to Democracy, The New York Times Bestseller.

Bauman, Z. (1991). Modernity and Ambivalence. Cambridge: Polity Press. 
Bergson, H. (1970). La Pensée et le mouvant. In: Oeuvres, éditions du Centenaire. Paris: P.U.F.

Berlin, I. (1981). Against the Current: Essays in the History of Ideas. Oxford: Oxford University Press.

Birch, C., \& Cobb Jr, J. (1981). The Liberation of Life: From the Cell to the Community. Cambridge: Cambridge University Press.

Bookchin, M. (1994). What is communalism?: The democratic dimension of anarchism. Green Perspectives, 31, 1-6.

Bookchin, M. (2004). Post-scarcity anarchism. $3^{\text {rd }}$ ed. Montréal: Black Rose.

Bookchin, M. (2007). Social ecology and communalism, ed. Eirik Eiglad. Oakland: AK Press.

Caluwe, de J., \& Verstraeten, G. M. J. (2014). In Defence of Leopold's Land-Ethics as a Global Environmental Approach for Cross-Cultural Dialogue. Presentation $9^{\text {th }}$ International Conference for Applied Sciences. 31 October-2 November 2014, Sapporo, Japan.

Caluwe, de J., \&Verstraeten, G. M. J. (2015). A Global Environmental Approach for Cross-Cultural Dialogue:from Noah's Ark to Security of Flourishing Homelands. Applied Ethics. Security, Sustainability and Human Flourishing. Chapter 6. Publisher: Center for Applied Ethics and Philosophy, Hokkaido University Sapporo, Japan. Editors: Center for Applied Ethics and Philosophy, Sapporo, pp. 64-80.

Certeau, de M. (1980). L'Invention du Quotidien . Paris: UG.

Clynes, M., \& Kline, N. (1995). Cyborgs and Space. Astronautics and 'Cyborg II'in Gray's Cyborg's Handbook.

Eco, U. (2012). It's Culture, not War, that Cements European Identity. La Stampa interview by Giani Rota, 26 January 2012.

Ellul, J. (1964). The Technical Change, translation J. Wilkinson, New York: Vintage.

Etzioni, A. (1996). The New Golden Rule. Community and Morality in a Democratic Society. New York: Basic Books.

Evanoff, R. (2010). Bioregionalism and Global Ethics: A Transactional Approach to Achieving Ecological Sustainability, Social Justice and Human Well-being. chapter 14. London: Routledge.

Foucault, M. (1976). Histoire de la Sexualité I: La Volonté du Savoir. Paris: Gallimard.

Fox, W. (1986). Approaching Deep Ecology: AResponse to Richard Sylvan's Critique of Deep Ecology. Environmental Studies Occasional Paper 20, Tasmania.

Fox, W. (1990). Toward Transpersonal Ecology: Developing New Foundations for Instrumentalism, Shambhala publications, Boston, Massachusetts.

Gadamer H. G. (1977). Philosophical Hermeneutics, (translated by David E. Linge). University of California Press.

Gadamer, H. G. (1975). Truth and Method. Sheed and Ward, London: Ltd Press.

Hacking, I. (1999). The social construction of what? Massachusetts: Harvard University Press.

Hall, E. T. (1990). Understanding Cultural Differences. Germans, French and Americans. Maine: Yourmath.

Haraway, D. (1996). Modest_Witness@Second_Millennium. FemaleMan_Meets_OncoMouse. Feminism and Technoscience. London: Routledge.

Heidegger, M. (1977). The Question Concerning Technology. Translation W. Lovitt. New York: Harper \&Row.

Hofstede, G. (2001). Culture's Consequences. California: Sage Publications.

Klückhone, C. K. M. (1962). Culture and Behaviour. Free Press of Glancoe.

Kymlicka, W. (2002). Contemporary Political Philosophy: An Introduction. Oxford: Oxford University Press.

Leopold, A. (1949). A Sand County Almanac. New York: Oxford University Press.

Locke, J. (1963). Two Treatises of Government, ed, P. Lasien, Cambridge: Cambridge University Press.

Lyotard, J. F. (1983). Le Différend. Paris: Minuit.

MacIntyre, A. (1981). After Virtue: A Study in Moral Theory. London: Duckworth.

MacPherson, C. B. (1977). Life and Time of Liberal Democracy. Wynford Project, North Yorkshire

Neumann, I. (1992). 'Rethorical Slavery, Rethorical Citizenship’, Michigan Law Review, 90, 1276. https://doi.org/10.2307/1289413

Parekh, B. (2006). Rethinking Multiculturalism : Cultural Diversity and Political Theory. London: Paperback Edition-29. https://doi.org/10.1007/978-0-230-20425-6 
Poincaré, H. (1913). La valeur de la science. Paris: Flammarion.

Rijnvos, C. J. (1996). Filosofie van tijd en ruimte. Ontwerp van een humane wijsbegeertee. Utrecht: Lemma BV.

Roshwald, A. (2006). The Endurance of Nationalism. Cambridge: Cambridge University Press.

Sandel, M. (1982). Liberalism and the Limits of Justice. Cambridge: Cambridge University Press.

Sandel, M. (1984). The Procedural Republic and the Unencumbere Self. Political Theory, 12(1), 81-96. https://doi.org/10.1177/0090591784012001005

Smith, A. (2003). "Eternal Care of Nation”, in Chosen People, 213. Oxford University Press.

Strasser, S. (1981). De Burger voorbij: ethische politieke overwegingen, Baarn: Ambo.

Taylor, C. H. (2004). Modern Social Imaginary. Durham and London: Duke University Press.

Taylor, Ch. (1992). 'The Politics of Recognition`, in Gutmann (ed.) Multiculturalism and the Politics of Recognition`. Princeton: Princeton University Press, 25-73.

Tuan, Y. F. (1974), Topophilia: Q Study of Environmental Perception Attitudes, and Values, Prentice Hall, Englewood Cliffs.

Verstraeten, G. J. M., \& Verstraeten, W. W. (2005a). Grenzen van dialoog. Het eco-communautarisme als alternatief voor het postmodernisme. Budel: Damon.

Verstraeten, G. J. M., \& Verstraeten, W. W. (2005b). Sociaal constructivisme, Leibniziaanse ruimte en ecocommunautarisme: 'Eén en al natuur'versus 'cést ma nature'. Een alternatief voor de multiculturele dialoog https://repub.eur.nl/pub/7087/.

Verstraeten, G. J. M., \& Verstraeten, W. W. (2014b). Eco-refuges as Anarchist's Promised Land or the End of Dialectical Anarchism. Asian Journal of Humanities and Social Studies, 2(6), 781-788.

Verstraeten, G. J. M., \& Verstraeten, W. W. (2016). Disentangling the Enlightenment's Paradox about Human Rights, National States and Global Migration: Towards an Eco-ethical Alternative. Asian Journal for Humanities and Social Studies, 4(6).

Verstraeten, G. J. M., \& Verstraeten., W. W. (2014a). From Particular Times and Spaces to Metaphysics of Leopold's Ethics of the Land. Asian Journal of Humanities and Social Studies, 2(1), 66-75.

Vick, B. E. (2002). Defining Germany: The 1848 Frankfurt Parliamentarians and National Identity. Cambridge, Massachusetts: Harvard University Press.

Voltaire, F. M. A. (1928). Dictionnaire philosophique.Tome V. Oeuvres Complets de Voltaire. Tome xxxvii. Paris: Renouard.

Waldron, J. (2000). Cultural Identity and Civic Responsibility, in W. Kymlicka and W. Norman (eds.) https://doi.org/10.1093/019829770X.003.0006

Weber, M. (1994). Political Writings (Cambridge Texts in the History of Political Thought). Ed. Peter Lassman. Trans. Ronald Speirs. Cambridge UP, xvi.

Zerubavel, E. (2003). Time Maps Collective Memory and the Social Shape of the Past. Chicago: University Press. https://doi.org/10.7208/chicago/9780226924908.001.0001

\section{Copyrights}

Copyright for this article is retained by the author(s), with first publication rights granted to the journal.

This is an open-access article distributed under the terms and conditions of the Creative Commons Attribution license which permits unrestricted use, distribution, and reproduction in any medium, provided the original work is properly cited. 